\title{
Educational pamphlets on health: a reception study
}

\author{
Folhetos educativos em saúde: estudo de recepção \\ Folletos educativos en salud: estudio de recepción
}

Évelyn Aparecida Nascimento ${ }^{1}$, Rita Maria Lino Tarcia ${ }^{2}$, Lidiane Pereira Magalhães ${ }^{3}$, Mariângela Abate de Lara Soares ${ }^{4}$, Maria Lucia Fernandez Suriano ${ }^{5}$, Edvane Birelo Lopes De Domenico ${ }^{6}$

\begin{abstract}
${ }^{1}$ Resident Nurse, Multiprofessional Residency Program in Oncology, São Paulo Hospital of the Universidade Federal de São Paulo, São Paulo, SP, Brazil.

${ }^{2}$ Adjunct Professor, Department of Health Information, Paulista School of Medicine, Universidade Federal de São Paulo, São Paulo, SP, Brazil.

${ }^{3}$ Nutritionist, Department of Clinical and Experimental Oncology, Universidade Federal de São Paulo, São Paulo, SP, Brazil.

${ }^{4}$ Substitute Adjunct Professor, Department of Pediatric Nursing, Paulista School of Nursing, Universidade Federal de São Paulo, São Paulo, SP, Brazil.

${ }^{5}$ Nurse, Department of Clinical Nursing and Surgery, Paulista School of Nursing, Universidade Federal de São Paulo, São Paulo, SP, Brazil.

${ }^{6}$ Adjunct Professor, Department of Clinical Nursing and Surgery, Paulista School of Nursing, Universidade Federal de São Paulo, São Paulo, SP, Brazil.
\end{abstract}

\begin{abstract}
Objective: Identifying the socioeconomic and cultural profile of users/readers of educational pamphlets, characterizing the context of the reading material and people involved; describing the user/reader evaluation on language and style used, as well as content range or limitations, and its characterization as an educational material in assisting users for meeting homecare demands. Method: A reception, cross-sectional, qualitative study. 27 respondents who had received five educational pamphlets were interviewed on Oncology signs and symptoms during primary care consultations. Results: Study participants were adults, with average schooling of more than 10 years and low income. Pamphlets were assessed as appropriate for consistent language, quantity and quality of content, and especially in relation to the capacity of helping in the homecare decision making process. The importance of receiving pamphlets at the initial stage of the disease was verified. Conclusion: Users acceptance was positive and the study revealed aspects that should be reinforced in the creation of educational pamphlets.
\end{abstract}

\section{DESCRIPTORS}

Health Education; Oncology Nursing; Evaluation Studies. 


\section{INTRODUCTION}

The communication between the healthcare team and the patient, their family or caregivers, is critical to patient safety and quality of care. This process involves exchange of information where patients, families and caregivers should be encouraged to participate in the care, encouraged to ask questions, direct dialogue and receive desired and necessary information ${ }^{(1-2)}$.

There is consensus among professionals in the healthcare practice that they must meet demands of information on diagnostic and therapeutic procedures, facilitate adaptation to clinical situations, attenuate anxiety of painful procedures, modify risky habits and promote treatment adherence $^{(2)}$. Verbal communication is one way of encouraging that these demands are met, although in some cases it may be accompanied by printed health materials. However, such materials are rarely evaluated for their capacity of complementing verbal information and for being useful for their proposed purposes ${ }^{(3)}$.

Although many health institutions nationwide use educational materials developed by their own professionals or by governmental agencies, research institutes, associations or others, there are only a few in-depth evaluation studies on their results. The role that printed health materials effectively play in communication between professionals and users of health services is unknown most of the time.

The World Health Organization (WHO) is concerned with the advancing number of patients with chronic diseases and the extent of the age of affected individuals, and so has recommended the establishment of educational processes that excel in generating knowledge, autonomy and management capacity for the healthcare of these individuals ${ }^{(4-6)}$.

As a group of teachers and students aware of this problem at different levels of training in Health (lato sensu and stricto sensu graduation), we started collecting produced educational pamphlets in an extension program of the Federal University of São Paulo (UNIFESP) entitled AcolheOnco: interdisciplinarity in the holistic care of patients with cancer, which aims at providing interdisciplinary care and education for self-management of the healthcare provided to oncology ward users and patients of a public hospital ${ }^{(7)}$.

Self-management is a conceptual reference of the program and it consists of a coordinated set of activities aimed at developing skills for decision making of patients and their caregivers or family members in situations that permeate the disease chronicity process $^{(8-9)}$.

The pamphlets were developed separately for the most frequently occurring signs and symptoms in patients undergoing clinical treatment. Direct and expressive language was used in its preparation. Direct language was mainly used in order to prevent or minimize risk behaviors, avoiding the imperative form ${ }^{(3,10)}$. Expressive language was used to allow expression of emotions and to approach feelings inherent in the information in the text $t^{(3,10)}$. Information that should be interpreted as cautions for decision-making were followed by encouraging phrases for the capabilities of patients, families or caregivers to assess and safely decide, taking into account the risks triggered by health aggravation.
The need to know the users' perceptions about the educational material and the effectiveness of educational pamphlets used as support material from their perspective guided the formulation of the questions: How did the reading of the educational material happen at home? What is the importance given by the user to the pamphlets as part of educational action in health? What is the user's own assessment of the language style used and content range or limitations of the pamphlets? How did the educational material assist the user in relation to meeting homecare demands? Conforming to the objectives of: Identifying the socioeconomic and cultural profile of users/readers of educational pamphlets, characterizing the context of the reading material and people involved; describing the user/reader evaluation on language and style used, as well as content range or limitations, and its characterization as an educational material in assisting users for meeting homecare demands.

\section{METHOD}

\section{Type of Study}

A descriptive, cross-sectional, qualitative study, based on the assumptions ofa reception study, which is characterized by how people receive and what they do with information intended for them from different media ${ }^{(1,11)}$. This is a communication study that discusses the place of the receiversubject as an interactive space whose components depend on how the transmitter is positioned, the conception that they have of themselves and their receptor, as well as the inter-relationship established ${ }^{(10-12)}$.

The research was developed in the specialization clinic at the São Paulo Hospital of UNIFESP campus in the city of São Paulo, SP, Brazil. The main researcher collected data from May to June 2012, before or after outpatient care, attended by the medical and nursing teams, and both are members of the Acolhe-Onco Extension Program.

The inclusion criteria were: patients (or their caregivers) in clinical oncology treatment who presented signs and symptoms in previous consultations documented in the studied pamphlets (nausea and/or vomiting, appetite loss, taste changes, constipation, blood disorders - anemia, leukopenia, thrombocytopenia); had received educational Acolhe-Onco Extension Program pamphlets regarding these signs and symptoms in previous consultation(s); and were 18 years or older. We excluded patients in clinical treatment who did not mention having signs and symptoms in prior consultations along with those who had attested to not having read the received educational pamphlets.

We selected 30 candidates within the stipulated period of data collection, but later excluded three (two patients and a caregiver) as they reported that they had not read the educational pamphlets, so that the final sample consisted of 27 participants.

The research project was submitted to the Ethics Committee for Research and Education (CEP) of UNIFESP and was approved on 05/25/12, under No. 29,666. 


\section{Educational Action Design}

We carried out the procedures of construction and validation of educational materials and the development of the Acolhe-Onco Extension Program pamphlets ${ }^{(7)}$ between March 2010 and July 2011 in the Virtual Learning Environment VLE - Moodle (Modular Object-Oriented Dynamic Learning Environment) through wiki features that enable online collaborative construction.

For this study, the selected pamphlets were nausea and/ or vomiting, appetite loss, taste changes, constipation, and blood disorders (anemia, leucopenia, thrombocytopenia). Its contents include: conceptual introduction, occurrence context in oncology, guidelines and grading for severity for monitoring, management suggestions, and encouraging adoption of proactive and coping behaviors.

Professionals from the areas of nursing, medicine, nutrition and pharmacology from the same institution evaluated the pamphlets and we incorporated their suggestions. Later, we printed the pamphlets at the copy center and started handing them out in in-person consultations from December 2011.

After study participants signed the Informed Consent form, they were registered in a form provided for this research, including their name, contact number, consultation and return dates and pamphlet handouts. For the interview, we conducted an Assessment of Educational Pamphlet Guidelines by patient and/or Family and Caregiver, which took into account literature on acceptance studies and a data collection instrument in a similar study ${ }^{(12)}$, its use was previously authorized by the main author upon written request. The guideline contained data of subject's characterization: gender, age, nationality, origin, socioeconomic and cultural aspects, type of bond with the clinic (patient, family and/or caregiver), cancer diagnosis, time elapsed since first diagnosis and their level of understanding of the medical diagnosis. It was followed by 11 yes/no/why questions, which assessed the writing style, font and font size, the extent of pamphlets, the aspects that caught attention, the desire to share the material with others, the compatibility with the verbal directions and the ability to help decision-making at home. Questions 12 and 13 were the semi-structured questions of: In which ways do you think the educational material might help you in meeting your needs (or the needs of the patient, in the case of the respondent being a caregiver) regarding the care you need to receive at home? Describe the situation in which some information was useful.

The technique used for data analysis was Content Anal$\mathrm{ysis}^{(13)}$, which allows for the quantification and qualification of data. We implemented a set of methodological tools to ensure data objectivity and systematization, and to verify the influences present in many of the testimonies, seeking to extract the most relevant aspects. We used descriptive statistics for quantification.

\section{RESULTS}

Of the 27 subjects who participated in the study, 18 were patients, and 9 were caregivers or family members, with average ages of 47.5 and 49 years old, respectively.

For diagnoses, five patients had cancer in the colon and rectum, three in the head and neck, three hematologic, two renal, two soft tissue sarcomas and one case each for prostate, melanoma, bladder and adrenal. Respondents were identified with the letter $\mathrm{R}$ and assigned a random number from 1-27.

Regarding diagnosis time, cancer diagnoses were made in the following intervals: $27.77 \%(\mathrm{n}=5) 1$ to 6 months; $33.33 \%(n=6) 7$ to 12 months; $11.11 \%(n=2)$ up to 24 months and $77.77 \%(n=14)$ over 25 months. Note that in the latter percentage of $77.77 \%$, two respondents reported that their first diagnosis of cancer occurred 7 and 27 years earlier, respectively, and during the interview they were being treated for a second diagnosis.

We used descriptive statistical analyzes to identify similarities in the characterization of the subjects. Whenever possible, it was decided to unite the two groups of patients and caregivers or family members. The data of the socio-demographic and economic characteristics are presented in Table 1. 
Table 1 - Socio-demographic and economic characteristics of patients and caregivers - São Paulo, SP, Brazil, 2013.

\begin{tabular}{|c|c|c|c|c|c|c|}
\hline \multirow[t]{2}{*}{ Gender } & \multicolumn{2}{|c|}{ Patients } & \multicolumn{2}{|c|}{ Caregivers } & \multicolumn{2}{|c|}{ Total } \\
\hline & $\mathbf{N}$ & $\%$ & $\mathbf{n}$ & $\%$ & $\mathbf{N}$ & $\%$ \\
\hline Female & 5 & 27.77 & 7 & 77.77 & 12 & 44.45 \\
\hline Male & 13 & 72.22 & 2 & 22.22 & 15 & 55.55 \\
\hline \multirow[t]{2}{*}{ Place of Birth } & \multicolumn{2}{|c|}{ Patients } & \multicolumn{2}{|c|}{ Caregivers } & \multicolumn{2}{|c|}{ Total } \\
\hline & $\mathbf{N}$ & $\%$ & $\mathbf{n}$ & $\%$ & $\mathbf{n}$ & $\%$ \\
\hline São Paulo & 15 & 83.33 & 6 & 66.66 & 21 & 77.78 \\
\hline Pernambuco & 0 & 0.00 & 1 & 11.11 & 1 & 3.70 \\
\hline Minas Gerais & 1 & 5.55 & 0 & 0.00 & 1 & 3.70 \\
\hline Bahia & 2 & 11.11 & 1 & 11.11 & 3 & 11.11 \\
\hline Ceará & 0 & 0.00 & 1 & 11.11 & 1 & 3.70 \\
\hline \multirow[t]{2}{*}{ Education Level } & \multicolumn{2}{|c|}{ Patients } & \multicolumn{2}{|c|}{ Caregivers } & \multicolumn{2}{|c|}{ Total } \\
\hline & $\mathrm{N}$ & $\%$ & $\mathrm{n}$ & $\%$ & $\mathrm{n}$ & $\%$ \\
\hline None & 0 & 0.00 & 0 & 0.00 & 0 & 0.00 \\
\hline Incomplete Elementary Education & 5 & 27.77 & 3 & 33.33 & 8 & 29.63 \\
\hline Completed Elementary Education & 2 & 11.11 & 1 & 11.11 & 3 & 11.11 \\
\hline Incomplete High School & 2 & 11.11 & 3 & 33.33 & 5 & 18.52 \\
\hline Completed High School & 7 & 38.88 & 1 & 11.11 & 8 & 29.63 \\
\hline Incomplete Higher Education & 1 & 5.55 & 0 & 0.00 & 1 & 3.70 \\
\hline Completed Higher Education & 1 & 5.55 & 1 & 11.11 & 2 & 7.41 \\
\hline \multirow[t]{2}{*}{ Income } & \multicolumn{2}{|c|}{ Patients } & \multicolumn{2}{|c|}{ Caregivers } & \multicolumn{2}{|c|}{ Total } \\
\hline & $\mathbf{N}$ & $\%$ & $\mathbf{n}$ & $\%$ & $\mathbf{n}$ & $\%$ \\
\hline Up to 3 minimum wages & 7 & 38.88 & 5 & 55.55 & 12 & 44.44 \\
\hline from 3 to 5 minimum wages & 5 & 27.77 & 1 & 11.11 & 6 & 22.22 \\
\hline from 5 to 8 minimum wages & 2 & 11.11 & 1 & 11.11 & 3 & 11.11 \\
\hline More than 8 minimum wages & 2 & 11.11 & 0 & 0.00 & 2 & 7.4 \\
\hline Did not answer & 2 & 11.11 & 2 & 22.22 & 4 & 14.82 \\
\hline
\end{tabular}

Regarding the specific part of the data collection instrument, we encouraged respondents to remember educational pamphlets which were previously delivered to them and asked if they had felt the desire to read them and if they had shared them with anybody. Twenty-four (88.90\%) said they had read the material, $16(84.20 \%)$ were patients and eight $(75.00 \%)$ were caregivers.

The motivations mentioned by the respondents which led to them reading the pamphlets were: interest in learning about the disease and/or symptoms they had $(n=5)$ and the verbalization of pamphlet content by nurses, prior to receiving them $(\mathrm{n}=1)$. Three subjects $(11.11 \%)$ said they were not interested in reading the pamphlet, claiming they felt obliged to read due to illness condition they were in $(n=3)$ and they were unwilling to engage in any activity $(n=1)$. Among caregivers, the explanations given for the desire to read the pamphlets were curiosity $(n=2)$, and a desire to acquire information to help a sick family member $(n=1)$.

When asked about sharing educational pamphlets with others, 14 (51.85\%) (12 patients and two caregivers) re- ported having shared them; 13 (48.14\%) (seven patients and six caregivers) did not share the pamphlets with anyone else. Among the patients, the reasons for sharing pamphlets with others were: they perceived a need for aid in detecting and managing signs and symptoms and they had a desire to share them. Among the caregivers, the reasons were: they had a desire to share and they recognized the possibility of increasing the information about the disease process. Some passages exemplify these answers:

\section{I handed the pamphlets to my wife, so she could learn the content and help me determine the symptoms I had. Sometimes it is possible that you are so involved in the situation that you cannot determine which ones you are feeling (R16).}

I handed the pamphlets to my niece, because she always asks how the consultations were, so I wanted to show her what happened. I always tell her how the consultations went (R17).

When asked to whom pamphlets were shared with, patients reported sharing them with their spouse $(n=7)$; 
mother $(n=1)$; child $(n=3)$; niece $(n=1)$; brother $(n=2)$; granddaughter $(\mathrm{n}=1)$; sister $(\mathrm{n}=1)$, and the caregivers, being grandchildren $(\mathrm{n}=1)$ and siblings $(\mathrm{n}=1)$.

When asked about the clarity of pamphlets, one respondent did not consider them clear, as he judged that it is important to add information concerning possible approaches adopted by the health team. His testimony was:

\section{For each symptom generated by chemotherapy, the pamphlet should describe possible medical pro- cedures so that patients can talk to their doctors (R16).}

The others considered the pamphlets appropriate in regarding clarity of content, and offered the following voluntary statements: the pamphlets are easy to understand $(\mathrm{n}=10)$, they are clear $(\mathrm{n}=7)$, and they are objective $(\mathrm{n}=2)$.

As for the language, 26 respondents considered the terms used as appropriate, while one responded negatively to the question, since he identified the presence of some technical terms that interfered with his understanding. The majority (96.29\%) of the participants considered the vocabulary easy to understand $(\mathrm{n}=8)$, clear $(\mathrm{n}=5)$ and objective $(\mathrm{n}=1)$, having found no tecbnical terms or presence of explanation $(\mathrm{n}=9)$.

When asked about the size and type of font used, 26 (96.29\%) rated them as appropriate. Only one respondent disagreed, considering that the font could be bigger. Some spontaneous comments were: When asked about the size and type of font used, 26 (96.29\%) rated them as appropriate. Only one disagreed, considering that the letters could be larger. Some spontaneous comments: I can read perfectly with my glasses on $(\mathrm{n}=3)$; there was no difficulty in viewing the content $(\mathrm{n}=1)$; the font was normal/standard $(\mathrm{n}=3)$; You can still read it even if you have vision problems $(\mathrm{n}=2)$; the font used in the pamphlet is big $(\mathrm{n}=1)$.

In terms of the extent and amount of information on the educational pamphlet, $92.60 \%$ considered it was appropriate, some pointed out that it was suitable but extensive $(n=4)$. The remaining respondents $(7.41 \%)$ judged that there was an excessive amount of information, stating: this information was previously shown (R25) and I find the text repetitive and I'm selecting parts to read (R6).

As for the characterization of the range and possible limitations of the material, only six (22.22\%) respondents (all patients) would add information to the material. Suggested additions were: the consumption of acidic foods reduces the unpleasant taste in the mouth $(\mathrm{n}=1)$; chemotherapy can change the taste and odor of food and increase nausea $(\mathrm{n}=1)$; The use of sodium bicarbonate for brushing the teeth $(\mathrm{n}=1)$; descriptions of possible medical procedures for symptoms caused by chemotherapy $(\mathrm{n}=1)$; avoiding fruits and vegetables cultivated with pesticides since they may be harmful to the patient undergoing chemotherapy $(\mathrm{n}=1)$.

The response of the patient who did not answer affirmatively nor negatively is noteworthy, since he just wrote that there may be a conflict of information when a patient receives more than one type of educational pamphlet; for example that some foods that are harmful to someone with diarrhea, and some which are recommended for people with nausea and vomiting.
When the respondents were asked if the guidelines contained in the educational pamphlets were in accordance with the information provided by the health team, 21 (77.77\%) responded affirmatively and six (22.22\%) negatively. The respondents who disagreed cited the following main reasons: lack of verbal explanations on much of the information contained in the pamphlets in previous consultations; late receipt of the pamphlets when the symptoms were already present; possibly forgetting information received verbally because at that time there were no symptoms. Some declarations are presented below:

\section{Not all information contained in the pamphlet was mentioned by professionals, or they may have been mentioned, but because they were not a necessity for me back then I might not have paid attention (R7). \\ When I received the pamphlet, I already knew a lot of the information, so I consider that I re- ceived it somerwhat late (R9).}

As for the ability of educational pamphlets in assisting signs and symptoms generated by cancer treatments, 96.29\% answered affirmatively. Spontaneous comments were categorized as: educational pamphlets as guidelines for prevention and control, ability of the educational pamphlet to teach patients and the caregivers, and assistance to patients with hearing impairment. Some testimonials are presented below:

\section{The pamphlet has helped with food preparation. I read the pamphlet on constipation because it was the one that caught my attention the most, since I help in the preparation of my brother in law's meal. When his wife cannot prepare a meal or he is sick of her food, I help. It also helped by highlighting the importance of exercises, because he just wanted to lie down (R11). \\ The pamphlet helps those with hearing impair- ment by reinforcing learning (R12).}

In regards to the pamphlets' ability in stimulating patients or caregivers skills for self-management in homecare demands, the statements made reference to the fact that the educational materials were able to suggest practices for the management of signs and symptoms, and to inform and generate security and tranquility for home care. Among the testimonials we had:
The pamphlet helped me by giving tips on how to eat dry foods in the morning, as well as having cold drinks, so I could better manage the nausea and vomiting $(\mathrm{R} 5)$.
The pamphlet has enlightened me to offer my hus- band acidic foods so the oily taste he felt on his mouth improved (R15).

\section{DISCUSSION}

The study subjects were adults mostly over 40 years of age with a predominance of males among patients, and fe- 
male predominance among caregivers. Among the caregivers, the women were in charge, although male behavior of closer links to family activities is already expressed in society ${ }^{(14)}$.

The education level of most respondents was between elementary and completed high school, namely up to 10 years of formal schooling, an important aspect for the evaluation of a communication instrument in written language.

The time elapsed since diagnosis ranged from six to more than 25 months. This is also relevant ina reception study as it could imply obviousness or impropriation of content, since over a prolonged period of illness, patients and caregivers accumulate experience and knowledge about the condition. However, few respondents $(n=2)$ mentioned these concerns when asked about content adequacy.

Another analytical point regarding diagnosis time is related to the chronic nature that the disease may assume. In this scenario, health education is needed, mainly for self-management of the chronic condition and so that patients have quality of life $\mathrm{f}^{(4,8)}$. The educational intervention should occur early, as emphasized by a respondent in relation to receiving the material too late, when symptoms were already present.

Most cancer occurrence sites are included in official statistics. In countries with a large volume of financial resources, the predominant cancers are lung, breast, prostate and colon ${ }^{(15)}$. In average to low resource countries, the predominant cancers are stomach, liver, oral cavity and cervix, usually occurring simultaneously with others previously cited, depending on regional economic differences ${ }^{(15)}$.

Regarding the economic impact of Oncology, the low income of most respondents was something worth highlighting, since $66.66 \%$ indicated receiving up to five minimum wages. It is known that the suffering from cancer causes signs and symptoms that reflect in patient's capacity of performing daily activities, often with the need for specific dietary menus (especially hypercaloric ones), the need of dressing and the use of various accessories (probes, drains, catheters) $)^{(7,16)}$.

The majority of respondents evaluated that the educational pamphlets were clear, objective, easy to understand and had appropriate vocabulary, without technical terms, and that if present they were accompanied by explanations. The font size was considered clear, visible and readable. According to these data, pamphlets attended the required premise of speech equality: all with equal chance to make interpretations, statements, recommendations, explanations and justifications, as well as problematizing validity claims ${ }^{(1,3,11)}$.

For the ability to generate interest, the pamphlets were considered attractive to respondents, even those who testified a prior disinterest. In a chronic disease process such as cancer, emotional conflicts may appear, particularly if the disease is culturally stigmatized. The presence of signs and symptoms that interfere with vital energy, such as fatigue, fever, loss of appetite, among others, may also justify refusal or resistant behaviors to educational processes ${ }^{(16-17)}$.

In this sense, the presence of caregivers is crucial so the patient does not feel overwhelmed with information, a feeling that was attested to in the statements justifying the sharing of the materials, primarily with family members.
This sharing presented certain characteristics, such as the relationship most often with spouses and then with children; a predominance of women; physical proximity, considering who lives with the person who requires care, and emotional closeness, highlighting the marital relationship and the relationship between parents and their children ${ }^{(14)}$. Among the caregivers, material sharing was due to the sense of responsibility towards the patient and the health-disease process. This responsibility generally depends on the different degrees of emotional attachment, duty and obligation, desire to give back for the care received in childhood, an exchange of favors and even for the lack of other alternatives ${ }^{(14)}$.

Although many of the respondents were seen by the same professionals, we noted that the interactions occurred differently. Some testified that there was no explanation of all content present in the pamphlets. Literature shows that the association between educational pamphlets and verbal exposure is more effective ${ }^{(1,18-19)}$. This was also observed among spontaneous reports by patients and caregivers.

The development of printed educational materials is a complex process that must consider cultural aspects, based on a dialogical logic considering that both senders and receivers emit messages while none of the poles are passive or silent ${ }^{(2,18-19)}$. Understanding the demands of others and their interests is a prerequisite for effective learning when it comes to adult education ${ }^{(1,4,20)}$. This condition was signaled by a respondent who considered that a lot of information was received in face-to-face consultations which could lead to forgetfulness, valuing the written word as more favorable in the health education process.

Other data generated by this research with impact on patient safety was verified by the reality of ambulatory patients and their caregivers or family, in which $46.60 \%$ declared not residing in São Paulo, so that information and clarifications on how to react to dangerous homecare situations are a real need of this group and must be considered in the development of educational material.

Respondents showed understanding on the adequacy of the content and its ability to promote the development of skills for the decision making process. According to the respondents, the content that was missing provided two points of analysis: the plural character of care information which was not always convergent, and the understanding of some respondents about their rights, mainly in relation to the discussion of medical conduct. Patients and caregivers accumulate information through different sources, and not all are in accordance with the scientific literature. In addition, they expressed the need of knowing the correct behaviors/attitudes when facing complications in order to participate in decisions as subjects that exercise their citizenship rights.

\section{CONCLUSION}

Patients and caregivers with varied level of education participated in this study, predominantly until high school, and family incomes of up to five minimum wages. Almost all of the respondents expressed a willingness to read the 
educational materials and provided for better understanding of the cancer disease process. We highlight the importance of family in the process of sharing the information that comes from the material, reinforcing cultural aspects of the support network in chronic disease.

Respondents considered the pamphlet language clear, objective, without technical terms or, if present, had proper explanations concerning its meaning. As for their ability to contribute to the management of signs and symptoms resulting from the treatment or the disease itself, respondents evaluated that they were helpful, especially when pamphlets were offered before the occurrence of harmful effects.

We conclude that the educational pamphlets studied were able to guide homecare actions and to contribute to the development of patient or caregiver ability in decision making.

As for study limitations, it should be considered that the literature on acceptance studies recommends a prospective data collection for higher accuracy of results, as well as associations of dialogical techniques that could not be implemented due to time restraints.

\section{RESUMO}

Objetivo: Identificar o perfil socioeconômico e cultural de usuários de folhetos educativos, caracterizar o contexto de leitura do material e das pessoas envolvidas, descrever a avaliação dos usuários em relação ao estilo de linguagem empregada e a abrangência ou limitação dos conteúdos, caracterizar como o material educativo pôde auxiliar o usuário em relação ao atendimento das demandas de cuidados em domicílio. Método: Estudo de recepção, transversal, qualitativo. Foram entrevistados 27 respondentes que receberam cinco folhetos educativos sobre sinais e sintomas em Oncologia, durante o atendimento ambulatorial. Resultados: Os integrantes do estudo eram adultos, com escolaridade média acima de 10 anos e baixo poder aquisitivo. Os folhetos foram avaliados como adequados quanto à clareza de linguagem, quantidade e qualidade dos conteúdos e, principalmente, em relação à capacidade de auxiliar nas decisões tomadas em domicílio. Verificou-se a importância de seu recebimento na fase inicial da doença. Conclusão: A recepção dos usuários foi positiva e o estudo evidenciou aspectos que devem ser potencializados na elaboração dos folhetos educativos.

\section{DESCRITORES}

Educação em Saúde; Enfermagem Oncológica; Estudos de Avaliação.

\section{RESUMEN}

Objetivo: Identificar el perfil socioeconómico y cultural de usuarios de folletos educativos, caracterizar el contexto de lectura del material y las personas involucradas, describir la evaluación de los usuarios con respecto al estilo de lenguaje empleado y al alcance o limitación de los contenidos, caracterizar como el material educativo pudo auxiliar al usuario con respecto a la atención de las demandas de cuidados a domicilio. Método: Estudio de recepción, transversal, cualitativo. Se entrevistaron a 27 respondientes, quienes recibieron cinco folletos educativos acerca de las señales y los síntomas en Oncología, durante la atención ambulatoria. Resultados: Los integrantes del estudio eran adultos, con escolaridad media arriba de 10 años y bajo poder adquisitivo. Los folletos fueron evaluados como adecuados en cuanto a la claridad del lenguaje, la cantidad y calidad de los contenidos y, especialmente, con respecto a la capacidad de ayudar en las decisiones tomadas en domicilio. Se verificó la importancia de su recibido en la fase inicial de la enfermedad. Conclusión: La recepción de los usuarios fue positiva y el estudio evidenció aspectos que deben ser potenciados en el diseño de los folletos educativos.

\section{DESCRIPTORES}

Educación en Salud; Enfermería Oncológica; Estudios de Evaluación.

\section{REFERENCES}

1. Sousa-Muñoz RL, Fernandes BM, Sá RD, Rolim Filho AE, Athayde RAB, Duarte SGC, et al. Comunicação em saúde na atenção terciária: estudo exploratório sobre a informação retida pelo paciente. R Eletr Com Inf Inov Saúde [Internet]. 2012 [citado 2013 nov. 7]. 6(1):3-12 Disponível em: http://www.reciis.icict.fiocruz.br/index.php/reciis/article/view/436/971

2. DiMatteo MR, Haskard-Zolnierek KB, Martin LR. Improving patient adherence: a three-factor model to guide practice. Health Psychol Rev. 2012;6(1):74-91.

3. Freitas FV, Rezende Filho LA. Communication models and use of printed materials in healthcare education: a bibliographic survey. Interface. $2011 ; 15(36): 243-56$.

4. Organización Panamericana de la Salud. Cuidados innovadores para las condiciones crónicas: organización y prestación de atención de alta calidad a las enfermidades crónicas no transmisibles em las Américas. Washington: OPAS; 2013.

5. Nieuwlaat R, Wilczynski N, Navarro T, Hobson N, Jeffery R, Keepanasseril A, et al. Interventions for enhancing medication adherence. Cochrane Database Syst Rev. 2014;(11):CD000011.

6. McCue DA, Lohr LK, Pick AM. Improving adherence to oral cancer therapy in clinical practice. Pharmacotherapy. 2014;34(5):481-94.

7. De Domenico EBL, Machado RVP, Gelesson DD, Ribas C, Kater FR, Freire CAR, et al. Extensão universitária como espaço de vivência do cuidado integral em oncologia. Rev Ciênc Extensão [Internet] 2013 [citado 2014 mar 23];9(3):94-104. Disponível em: http://200.145.6.204/ index.php/revista_proex/article/view/559/903.

8. Houtum LV, Rijken M, Heijmans M, Groenewegen P. Self-management support needs of patients with chronic illness: do needs for support differ according to the course of illness? Patient Educ Couns. 2013;93(3):626-32.

9. McCorkle R, Ercolano E, Lazenby M, Schulman-Green D, Schilling LS, Lorig K, Wagner EH. Self-management: enabling and empowering patients living with cancer as a chronic illness. CA Cancer J Clin. 2011;61(1):50-62. 
10. White WJ. Disciplinarity and the rhetoric of science: a social epistemological reception study. Poroi [Internet] 2014 [cited 2015 Jan 07];10(2). Available from: http://ir.uiowa.edu/cgi/viewcontent.cgi?article=1130\&context=poroi

11. Grohmann R, Figaro R. O conceito de classe social em estudos de recepção brasileiros. ANIMUS Rev Inter Com Midiática [Internet] 2014 [citado 2015 jan. 08]; 13(25)._Disponível em: http://dx.doi.org/10.5902/2175497715775

12. Brasil FPS. Efeitos da apresentação de material educativo para pacientes com diabetes mellitus tipo 2 sobre o conhecimento da enfermidade e adesão ao tratamento [dissertação]. Brasília: Universidade de Brasília; 2009.

13. Bardin L. Análise de conteúdo. Lisboa: Edições 70; 2011.

14. Batista CMF, Bandeira MB, Quaglia MAC, Oliveira DCR, Albuquerque EPT. Sobrecarga de familiares de pacientes psiquiátricos: influência do gênero do cuidador. Cad Saúde Coletiva [Internet] 2013 [citado em 2014 maio 07];21(4):359-69. Disponível em http://www.scielo. $\mathrm{br} / \mathrm{pdf} / \mathrm{cadsc} / \mathrm{v} 21 \mathrm{n} 4 / \mathrm{v} 21 \mathrm{n} 4 \mathrm{a} 02 . \mathrm{pdf}$

15. Brasil. Ministério da Saúde; Instituto Nacional do Câncer José Alencar Gomes da Silva, Coordenação de Prevenção e Vigilância. Incidência de Câncer no Brasil: estimativa 2014 [Internet]. Rio de Janeiro: INCA; 2014 [citado 2014 maio 7]. Disponível em: http://www.inca.gov. br/estimativa/2014/estimativa-24042014.pdf

16. Steel JL, Geller DA, Robinson TL, Savkova AY, Brower DS, Marsh JW, et al. Health-related quality of life as a prognostic factor in patients with advanced cancer. Cancer. 2014;120(23):3717-21.

17. Oliveira PI de, Pereira CAC, Belasco AGS, Bettencourt ARC. Comparison of the quality of life among persons with lung cancer, before and after the chemotherapy treatment. Rev Latino Am Enfermagem. 2013;21(3):787-94.

18. Dowse R, Ramela T, Browne SH. An illustrated leaflet containing antiretroviral information targeted for low-literate readers: development and evaluation. Patient Educ Couns. 2011;85(3):508-15.

19. Dickinson R, Hamrosi K, Knapp P, Aslani P, Sowter J, Krass I, et al. Suits you? A qualitative study exploring preferences regarding the tailoring of consumer medicines information. Int J Pharm Pract. 2013;21(4):207-15.

20. Zanchetta MS, Pinto RM, Galhego-Garcia W, Cunha Z, Hésio A, Cordeiro FE, et al. Brazilian community health agents and qualitative primary healthcare information. Prim Health Care Res Dev. 2014 Apr 25. [Epub ahead of print]

Financial Support: Programa de Extensão Universitária PROEXT MEC-SESU. 2010-2011, Brazil. Edital n. XX. 